\title{
Impact of synthetic surfactants and oil dispersants on the gills of juvenile gilthead (Sparus aurata L.)
}

\author{
Maria Angela Masini, Paola Prato, Elisabetta Giacco, Gian Luigi Mariottini, Luigi Pane \\ Department of Earth, Environment and Life Sciences, University of Genoa, Italy
}

\begin{abstract}
Histological, scanning electron microscopic and immunohistochemical studies were performed on the gills of juvenile gilthead (Sparus aura$t a$ L.) exposed to various concentrations of three anionic detergents: sodium dodecyl sulphate (SDS), safety sea cleaner 2 (SSC2), and FINASOL OSR2, in short term ( $96 \mathrm{~h})$ and chronic (28 days) experiments. The mortality rate, median lethal concentration $\left(\mathrm{LC}_{50}\right)$ and the no observed effect concentration (NOEC), were calculated. At concentrations above $10 \mathrm{mg} / \mathrm{L}$, mortality was from 50 to $100 \%$ after exposure to SDS and SSC2, both in short term and chronic experiments. Gills were spongiotic and there were many lamellar fusions, membrane disruptions, hydropic degenerations and exfoliations of lamellar and interlamellar epithelium after $96 \mathrm{~h}$ of treatment and more markedly after chronic experiment. Microridges of the cell surface were less evident or absent. The enzymes of ion transport were down regulated. Exposure to FINASOL OSR2 (100 $\mathrm{mg} / \mathrm{L}$ ) showed no evident branchial alteration.
\end{abstract}

\section{Introduction}

Surfactants (surface-active agents) are detersive chemicals having a polar moiety (hydrophilic or lipophobic) and a non-polar moiety

Correspondence: Maria Angela Masini, Department of Earth, Environment and Life Sciences, University of Genoa, viale Benedetto XV 5, 16132 Genoa, Italy. Tel.: +39.010 .3538049 - Fax: +39.010 .3538047 .

E-mail: masini@unige.it

Acknowledgements: a deep gratitude goes to the beloved Prof. Uva Bianca Maria, who left a cultural and affective inheritance of incomparable and inestimable value. Thanks to Mabi.

Key words: surfactants, oil dispersants, toxicity, gills, Sparus aurata.

Received for publication: 12 February 2014.

Revision received: 27 October 2014.

Accepted for publication: 28 October 2014.

(C) Copyright M.A. Masini et al., 2014

Licensee PAGEPress, Italy

Journal of Biological Research 2014; 87:2296

doi:10.4081/jbr.2014.2296

This article is distributed under the terms of the Creative Commons Attribution Noncommercial License (by-nc 3.0) which permits any noncommercial use, distribution, and reproduction in any medium, provided the original author(s) and source are credited. (hydrophobic or lipophilic). They are broadly categorized as anionic, cationic, and nonionic or amphoteric according to the nature of the hydrophile moiety yielded in aqueous solution. Synthetic anionic surfactants have been used in increasingly high proportion as chemicals for household, personal care and industrial applications. ${ }^{1}$ A number of land-based waste products, notably surfactants, find their way down rivers to the seas..$^{2-4}$ Furthermore, there is a heavy maritime traffic of crude oils and their products that is prone to accidents, like ship grounding or collisions, resulting in oil spillage. Oil dispersants, that contain surfactants and/or solvent compounds that break down floating oil into small droplets within the water column, are the most commonly used. Ocean pollution levels in some areas have doubled every decade for the past fifty years and antifouling paints, as well as noxious liquid substances discharged into the sea from tank cleaning, may be added to sea water pollution. ${ }^{5}$

One of the most used synthetic surfactant is sodium dodecyl sulphate (SDS); its advantage lies in its ability to solubilize fats and oils, lower the surface tension of aqueous solutions, and form microemulsions. ${ }^{6}$ Sodium dodecyl sulphate is also used in pharmaceutical industries for its ability to increase intestinal absorption or in biological and biochemical research for its ability to solubilize lipid membranes; it has also been utilized for protein identifications by polyacrylamide gel electrophoresis (SDS-PAGE). ${ }^{7,8}$ An extended review on SDS has been offered by Singer and Tjeerdema. ${ }^{9}$ The possible toxicity of surfactants and oil dispersants has given rise to a number of research aiming to find new less toxic compounds; however, despite the research and the obvious usefulness of these chemicals, the doubt about a harmful effect on marine life still exists. SDS has both physical and biochemical effects on cells. Cell membranes lose their barrier capacity increasing their permeability ${ }^{10}$ at concentrations higher than critical micelle concentration (cmc) and cell lysis occur. ${ }^{11}$ In fish branchial epithelium exposed to saponins and synthetic surfactants, vacuolations and detachments of cells have been observed. ${ }^{12}$ Exposure of rainbow trout to Zephiran, a cationic quaternary ammonium compound used as detergent in the treatment of fish bacterial diseases, resulted in severe branchial lesions. ${ }^{13}$ Similarly, the toxic effect of anionic detergents was observed in rainbow trout Salmo gairdneri now known as Oncorhynchus mykiss ${ }^{14,15}$ and in the brown trout Salmo trutta ${ }^{15}$ in which the gill epithelium lifts away from the underlying tissue, and lymphocytes and granulocytes invade the subepithelial spaces.

Recently, the toxicity of some surfactants was assessed in the framework of studies aimed to evaluate the suitability of dispersants and sorbents to be employed for the decontamination of the marine environment after oil pollution. ${ }^{16}$

The toxicity of SDS and dispersants Antipetrol AP2 (AP), safety sea cleaner 2 (SSC2) and FINASOL OSR2 was tested on copepods Tigriopus fulvus ${ }^{17-19}$ observing that SDS and SSC2, and less AP, showed high toxicity both on nauplii and adults; on the contrary, FINASOL OSR2 was toxic only for larval stages. A similar sensitivity was recorded also for barnacle nauplii (Balanus amphitrite).$^{20}$ Surfactant toxicity in waterfowl was also described. ${ }^{21,22}$ Juvenile fish (Dicentrarchus labrax, 
Sparus aurata) exposed to SDS and SSC2 showed high sensitivity, ${ }^{23,24}$ while FINASOL OSR2 did not induce mortality also at concentrations $>2000 \mathrm{mg} / \mathrm{L}$ and did not cause alterations of the morphology of gills at the concentration of $100 \mathrm{mg} / \mathrm{L} .^{24}$

The aim of the present work was to test the toxicity of different concentrations of SDS, FINASOL OSR2 and SSC2 by the evaluation of alterations induced on the gills of the gilthead Sparus aurata L., considering that the gills are one of the most important barriers encountered by pollutants in the aquatic ecosystem. The lesions at branchial tissue level were observed by histology. Immunohistochemistry was used to reveal damages to the enzymes involved in transmembrane ion transport.

\section{Materials and Methods}

\section{Maintenance of fish}

Juveniles of Sparus aurata L. (Osteichthyes, Sparidae) were purchased from an Italian fish farm (Ca' Zuliani, Pila di Porto Tolle, Italy). Sparus aurata is a common Mediterranean species; it is euryaline and eurythermal and is found both in marine and, particularly during the early life stages, in brackish waters. It is also very sensitive to any environmental change, therefore S.aurata is useful for toxicological research. ${ }^{25}$

The specimens were transported to the laboratory and maintained in tanks (150 L) containing synthetic sea water (Instant Ocean ${ }^{\circledR}$; Aquarium System, Mentor, OH, USA) where they were acclimated for 5 weeks under laboratory conditions before the start of the experiment. Tanks were individually aerated and water was filtered with a flowthrough water supply. Water temperature was $20 \pm 0.5^{\circ} \mathrm{C}$. Animals were fed twice a week with commercial food ad libitum (progression fish starting diet; Salt Creek Feeds for Aquaculture, Salt Lake City, UT, USA). Food was withheld beginning 1 day before experimentation.

\section{Exposure to the surfactants and oil dispersant}

The effect of different concentrations of surfactants and oil dispersants on the gills was examined after short term (96 h) and long term (28 days) exposure. The different concentrations of SDS (Sigma Aldrich, St. Louis, M0, USA), FINASOL OSR2 (Total FINA ELF, Paris, France) and SSC2 (Blutec Chemicals S.r.L., Genoa, Italy) used are listed in Table 1.

Five juveniles for each chemical concentration and for the control were used in triplicate, maintained in $20 \mathrm{~L}$ tanks containing $10 \mathrm{~L}$ artificial sea water, according to the Organization for Economic Cooperation and Development. ${ }^{26,27}$ Food was supplied every $48 \mathrm{~h}$ and after $1 \mathrm{~h}$ the water was changed and the chemicals were added (semistatic test). Lethal concentration $50 \%\left(\mathrm{LC}_{50}\right)$ was calculated using the Trimmed Spearman-Karber method. ${ }^{28}$ The no observed effect concentration (NOEC) was measured using the Dunnett test and statistically evaluated with ANOVA.

\section{Histopathology}

The toxic effect of tested chemicals on branchial tissue was analyzed on the survived animals that were killed by deep anaesthesia with MS
22 SAND0Z, 2-4 g/L (Sigma Aldrich). The gills were processed for light microscopy (LM), scanning electron microscopy (SEM) and immunohistochemistry.

Branchial tissue for LM was fixed in paraformaldehyde $4 \%$ (Immunifix Bioptica). Paraplast sections were cut at $5 \mu \mathrm{m}$, stained with haematoxylin and eosin and observed with a Leica DM light microscope (Leica Microsystems GmbH, Wetzlar, Germany). Gills for SEM were fixed in $2.5 \%$ glutaraldehyde in $0.1 \mathrm{M}$ cacodylate buffer, $\mathrm{pH} 7.4$, for $3 \mathrm{~h}$ at $4^{\circ} \mathrm{C}$, and then dehydrated in ethanol with increasing concentration up to $100 \%$ and critical point dried with liquid $\mathrm{CO}_{2}$ as transition fluid. ${ }^{29}$ They were mounted with double-sided adhesive tape on aluminium stubs and coated with a $20 \mathrm{~nm}$ gold layer in an argon atmosphere flow discharge sputter coating-unit (Polaron E 5100). The gills were examined in an ISI SS-40 SEM operated at an accelerating voltage of $10-20 \mathrm{kV}$.

The presence of enzyme involved in trans membrane ion transport was observed by immunohistochemistry ${ }^{30}$ using the following antibodies: Ab to $\mathrm{Na}^{+} / \mathrm{K}^{+}$ATPase $(\alpha 5$, monoclonal, donor animal mouse, IgG1 kappa light chain) and $\mathrm{Na}^{+/} \mathrm{K}^{+} / \mathrm{Cl}^{-}$cotransporters $\mathrm{NKCC}_{1}-\mathrm{T}_{4}$ (T4, monoclonal, donor animal mouse, IgG1). The antibodies were obtained from the Developmental Studies Hybridoma Bank, created by the Eunice Kennedy Shriver National Institute of Child Health and Human Development of the National Institute of Health and maintained at the University of Iowa (Department of Biology, Iowa City, IA, USA). Briefly after exposure to normal goat serum [diluted 1:50 in phosphate buffered saline (PBS); Sigma Aldrich] in a humid chamber at $20^{\circ} \mathrm{C}$, the sections were incubated overnight at $4^{\circ} \mathrm{C}$ with the primary antisera. After PBS washing $(0.01 \mathrm{M}, \mathrm{pH} 7.4)$ a second layer of fluoresceine-isothiocyanate conjugated $\gamma$-globulins (FITC), goat anti-mouse (diluted 1:100 in PBS; Sigma Aldrich) was applied for 30 min into a humid chamber, at $20^{\circ} \mathrm{C}$. The slides were rinsed in PBS at $20^{\circ} \mathrm{C}$ for $30 \mathrm{~min}$, mounted with gelmount (Biomeda Corp., Foster City, CA, USA). The specificity of the immunostainings was verified by omitting one of the steps of the immunohistochemical procedure, or by replacing the primary antibodies with PBS. As positive controls, gills sections of Pagetopsis macropterus were incubated with $\mathrm{Ab}-\mathrm{Na}^{+} / \mathrm{K}^{+} \mathrm{ATP}$ ase and to $\mathrm{Ab}-\mathrm{Na}^{+} / \mathrm{K}^{+} / \mathrm{Cl}^{-}$cotransporter. ${ }^{31}$ Immunoreactions were visualized using a Leica DMRB epifluorescence microscope (Leica Microsystems $\mathrm{GmbH}$ ).

\section{Results}

The two applied timeframe (short and extended) assays showed different survival of juveniles after exposure to the different concentration and the different chemical used. In all experiments the mortality in controls was less than $10 \%$.

\section{Sodium dodecyl sulphate exposure}

The acute short term $(96 \mathrm{~h})$ assay showed $100 \%$ mortality at the higher concentration $(20 \mathrm{mg} / \mathrm{L})$. At the concentration of $10 \mathrm{mg} / \mathrm{L}$ the mortality was about $50 \%$. Lower concentrations resulted in a $100 \%$ survival. The $\mathrm{LC}_{50}$ value resulted $8.6 \mathrm{mg} / \mathrm{L}$ (confidence limits 7.9-9.4 mg/L) (Table 2). At long term exposure (28 d) the NOEC (mortality) was $5 \mathrm{mg} / \mathrm{L}$.

Table 1. Concentrations of chemicals used in the tests on Sparus aurata.

\begin{tabular}{lccc} 
Test & SDS $(\mathrm{mg} / \mathrm{L})$ & FINASOL OSR2 $(\mathrm{mg} / \mathrm{L})$ & SSC2 $(\mathrm{mg} / \mathrm{L})$ \\
Short term $(96 \mathrm{~h})$ & $1.25,2.5,5,10,20$ & $10,20,100,200,500,1000,2000$ & $0.1,1,10,25,50$ \\
Long term (28 d) & $1.25,2.5,5,10,20$ & $10,20,100,200,500,1000,2000$ & $2.5,5,7.5,10,12.5$ \\
\hline
\end{tabular}

SDS, sodium dodecyl sulphate; SSC2, safety sea cleaner 2. 


\section{Safety sea cleaner 2 exposure}

The acute short term exposure $(96 \mathrm{~h})$ to $\mathrm{SSC} 2$ resulted in a $\mathrm{LC}_{50}$ of $18.6 \mathrm{mg} / \mathrm{L}$ (confidence limits 17.1-20.3 mg/L), while the NOEC (mortality) after long term exposure (28 d) was $10.0 \mathrm{mg} / \mathrm{L}$ (Table 2 ).

\section{FINASOL OSR2 exposure}

The acute short term exposure $(96 \mathrm{~h})$ revealed that the $\mathrm{LC}_{50}$ was not detectable, thus the chemical, according to the Group of Experts on the Scientific Aspects of Marine Environmental Protection was not toxic. In the long term exposure the NOEC (mortality) was $1000 \mathrm{mg} / \mathrm{L}$ (Table 2).
Histomorphological results:

\section{sodium dodecyl sulphate exposure}

After exposure to a SDS concentration of $1.25 \mathrm{mg} / \mathrm{L}$ the branchial tissue appeared normal, however after exposure to a concentration of $20 \mathrm{mg} / \mathrm{L}$ the gills showed severe damages that included expansion of the lymphatic channels, cell membrane vesiculation and exfoliation of lamellar and interlamellar epithelium both in short term and chronic exposure. Blood cells were seen in the lymphatic spaces (Figure 1a,b). The SEM analysis showed disruption of the micro-ridges, cells degenerations and immature replacing sloughed ones (Figure 2a,b). The enzyme mechanisms of the

Table 2. $\mathrm{LC}_{50}$ with confidence limits $(96 \mathrm{~h})$ and no observed effect concentration ( $28 \mathrm{~d}$ ) values calculated after exposition of Sparus aurata juveniles to sodium dodecyl sulphate, safety sea cleaner 2 and FINASOL OSR2.

\begin{tabular}{lcc} 
Compound & $\begin{array}{c}\mathrm{LC}_{50} \\
(\mathrm{mg} / \mathrm{L})\end{array}$ & $\begin{array}{c}\text { NOEC } \\
(\mathrm{mg} / \mathrm{L})\end{array}$ \\
SDS & $8.6(7.9-9.4)$ & $5(\mathrm{P}<0.05)$ \\
SSC2 & $18.6(17.1-20.3)$ & $10(\mathrm{P}<0.05)$ \\
\hline FINASOL OSR2 & $\mathrm{nc}$ & $1000(\mathrm{P}<0.05)$ \\
\hline
\end{tabular}

$\mathrm{LC}_{50}$, median lethal concentration; NOEC, no observed effect concentration; SDS, sodium dodecyl sulphate; SSC2, safety sea cleaner 2; nc, not calculable.
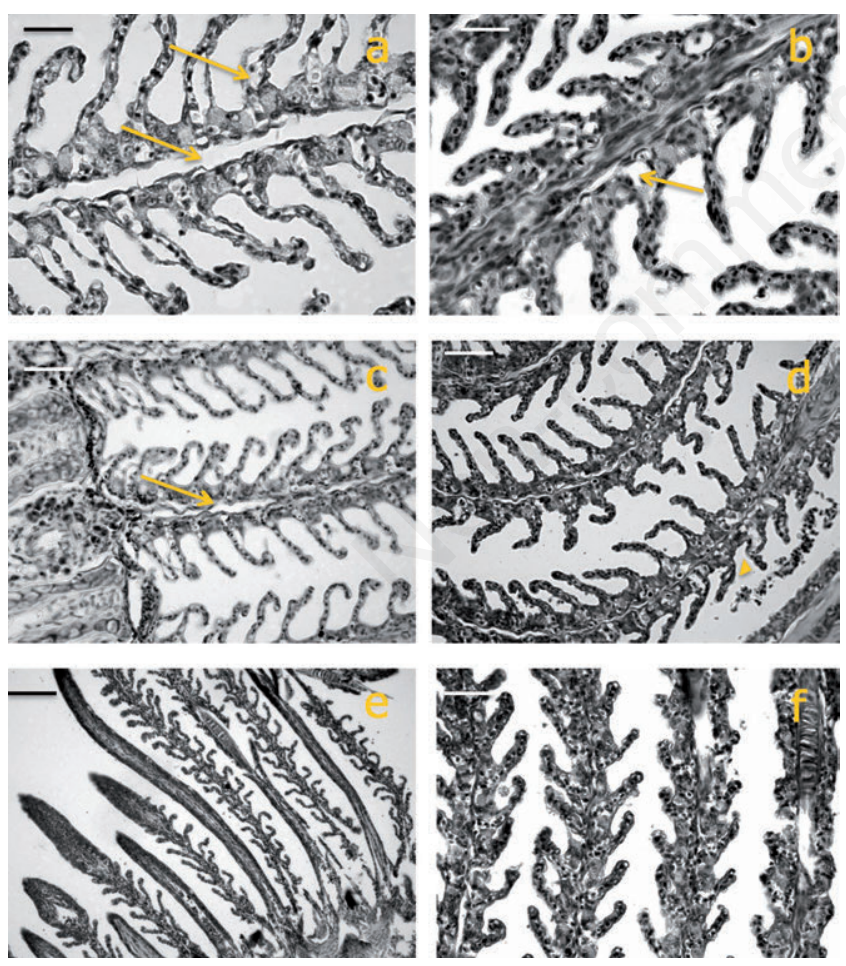

Figure 1. Haematoxylin and eosin light micrographs of branchial lamellae from Sparus aurata exposed to $20 \mathrm{mg} / \mathrm{L}$ sodium dodecyl sulphate (a,b), $20 \mathrm{mg} / \mathrm{L}$ safety sea cleaner 2 (c,d), $1000 \mathrm{mg} / \mathrm{L}$ FINASOL OSR2 (e) to be compared with the control (f). Note the expansions of the lymphatic channels in a), b), c) (arrows), the hydropic degeneration and the exfoliation of lamellar epithelium in d) (arrowhead). The branchial tissue after FINASOL OSR2 exposure is not damaged (e) and is similar to the controls ( $\mathrm{f}$ ). Scale bars: a) $100 \mu \mathrm{m}$; b) $150 \mu \mathrm{m}$; ) $100 \mu \mathrm{m}$; d) $150 \mu \mathrm{m}$; e) $350 \mu \mathrm{m}$; f) $200 \mu \mathrm{m}$.
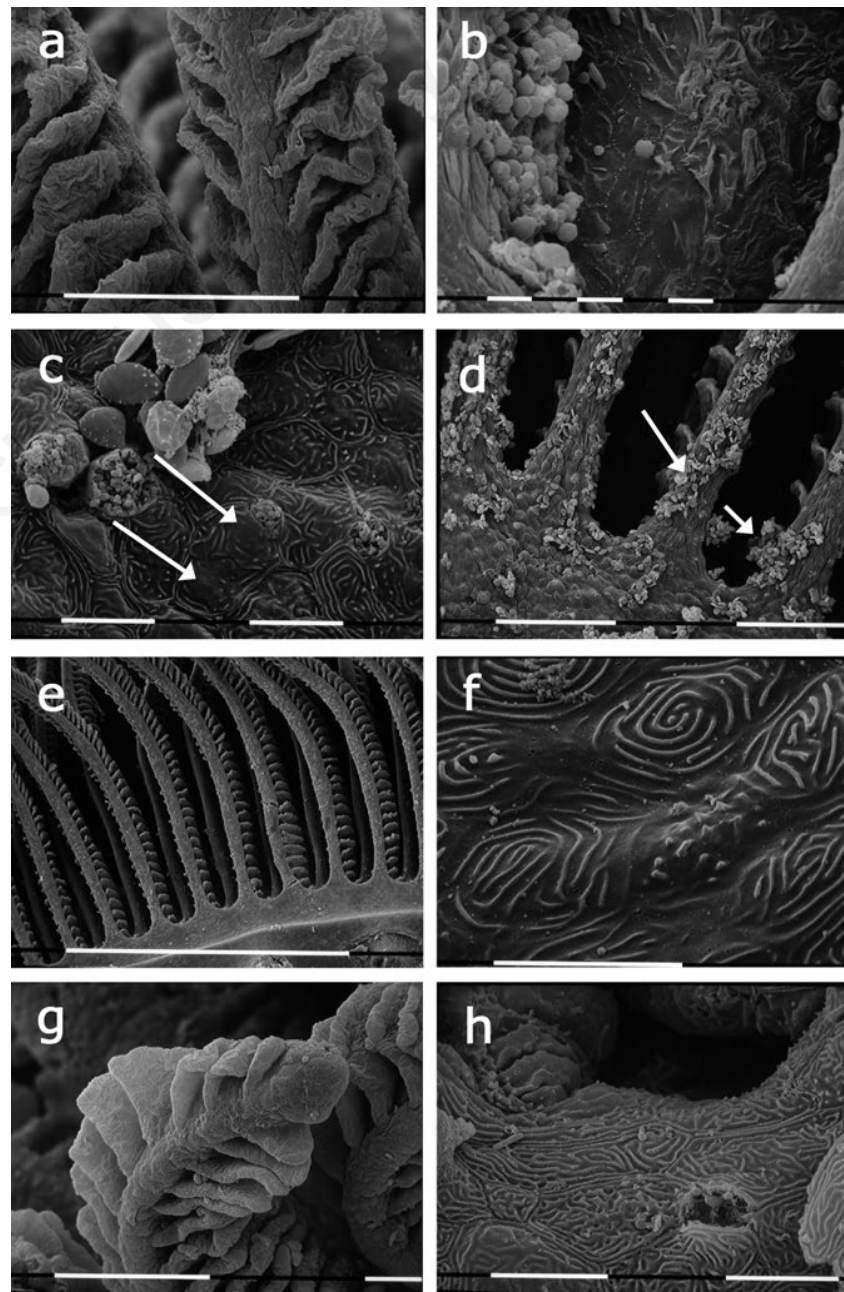

Figure 2. Scanning electron micrographs of branchial lamellae from Sparus aurata exposed in acute experiments to $20 \mathrm{mg} / \mathrm{L}$ sodium dodecyl sulphate $(\mathrm{a}, \mathrm{b}), 20 \mathrm{mg} / \mathrm{L}$ safety sea cleaner $2(\mathrm{c}, \mathrm{d})$ and $1000 \mathrm{mg} / \mathrm{L}$ FINASOL OSR2 (e,f). Controls are given in $\mathrm{g}$ ), h). Note the swollen cells in (a) as the result of spongiosis and hydropic degeneration. Note the reduced number or the absence of microridges in b) and c) (arrows), and the altered aspect of the secondary lamellae in d) (arrows). The gills of $S$. aurata exposed to FINASOL OSR2 show a normal aspect $(e, f)$ as seen in the controls (g,h). Scale bars: a) $90 \mu \mathrm{m}$; b,c) $15 \mu \mathrm{m}$; d) $150 \mu \mathrm{m}$; e) 540 $\mu \mathrm{m}$;) $15 \mu \mathrm{m}$; g) $95 \mu \mathrm{m}$; h) $15 \mu \mathrm{m}$. 
cells, as seen by the $\mathrm{Na}^{+} / \mathrm{K}^{+} / \mathrm{ATPase}$ and the $\mathrm{Na}^{+} / \mathrm{K}^{+} / \mathrm{Cl}^{-}$cotransporter immunoreactivity appeared to be normal after exposure to $1.25 \mathrm{mg} / \mathrm{L}$. The exposure to $20 \mathrm{mg} / \mathrm{L}$ resulted in severe histomorphological alterations, and the enzyme-immunoreactive cells appeared to be less numerous (Figure 3a) if compared with the control (Figure 3d).

\section{Histomorphological results: safety sea cleaner 2 exposure}

Effects similar to those occurring following the SDS treatments were observed after short term exposure to a concentration of $25 \mathrm{mg} / \mathrm{L}$ of SSC2; spongiosis was associated with expansion of the lymphatic channels. Exfoliation was observed in the lamellar and interlamellar epithelium, the secondary lamellae were almost disrupted, the pavement cells showed outer membrane lesions with extrusion of cytoplasmatic material, micro-ridges were less evident and seem to be interrupted (Figures 1c,d, 2c,d, arrows). The enzyme immunoreactive cells decreased in comparison with the controls (Figure $3 b$ ).

\section{Histomorphological results: FINASOL exposure}

Exposure to FINASOL ( $100 \mathrm{mg} / \mathrm{L})$ showed no evident alterations at branchial epithelium level (Figure 1e) when the tissue is observed at Light Microscope, but the SEM micrograph revealed that the microridge are lower (Figure 2e,f) if compared with the control (Figure 2h). The immunoreaction for the enzymes revealed a distribution and a brightness similar to the control (Figure 3c). A far more elevated concentration $(1000 \mathrm{mg} / \mathrm{L})$ was needed to cause damages to the gills.

\section{Controls}

All histomorphological results were compared with the aspects offered by the controls (Figures 1f, 2g,h, 3d) where the branchial epithelium is composed by pavement cells (distributed both in the primary and secondary lamellae), by mucous cells and chloride cells (characterised by a high mitochondrial density), numerous in the interlamellary space of the primary lamellae; the respiratory lamellae project at regular intervals from the primary lamellae.
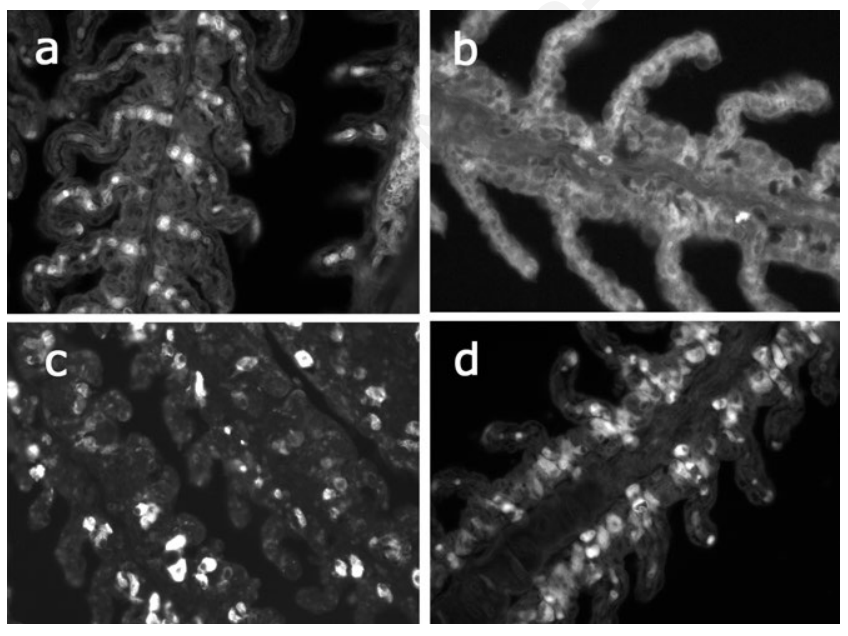

Figure 3. Immunohistochemistry for $\mathrm{Na}^{+} / \mathrm{K}^{+} \mathrm{ATPase}$ in branchial lamellae from $S$. aurata. The immunostaining is less in sodium dodecyl sulphate (a) and safety sea cleaner 2 (b) exposed animals if compared with the FINASOL OSR2 exposed (c) and control fish (d). In a) and b) blood cells are fluorescent. Scale bars: a,c,d) $50 \mu \mathrm{m}$; b) $65 \mu \mathrm{m}$.

\section{Discussion}

The purpose of this paper was to provide evidence of potential changes in branchial tissue of the juvenile gilthead (Sparus aurata) exposed in acute and chronic experiments to various concentrations of three anionic detergents (SDS, SSC2 and FINASOL OSR2). The results of this study have confirmed the high mortality of the fish at medium and high concentration of SDS, according to what is known about the toxicity of SDS in fishes, ${ }^{32}$ and SSC2, as reported earlier. ${ }^{24}$ At branchial level it was found that the gills underwent critical changes thereby confirming severe respiratory distress. Hypoxia may therefore be the cause of mortality. The branchial architecture was disrupted, histology and SEM revealed cell membranes disorganizations. Plasma membrane however was not completely destroyed, but the hydropic degeneration and spongiosis of the lamellar and interlamellar epithelia were presumably the result of water influx caused by membrane impairment and junctional porosity. Plasma membrane damage was probably due to the breakdown of various cellular enzyme systems and of proteins, such as ATPases, associated to the plasma membrane which could be denaturised. ATPases are crucial for the active exchange of sodium, potassium and chloride, and thereby osmoregulation was impaired. Our findings are similar to those reported by Abel and Skinmore ${ }^{14}$ in trout gills exposed to ionic detergent.

The range of lesions reported in this study are typical of fish exposed to surfactants and oil dispersant because they have been reported previously in fish exposed to branchial irritants, ${ }^{33}$ cationic detergents such as Zefiran ${ }^{13}$ and to SDS in the gilthead Sparus aurata. ${ }^{34}$ On the other hand, the sensitivity of juvenile Dicentrarchus labrax and Sparus aurata to SDS and SSC2 is well known. . $^{23,24}$

Gills are one of the first barriers encountered by pollutant before reaching the blood stream; therefore, gills integrity is essential to prevent contamination by different pollutants in fish organs and muscles.

\section{Conclusions}

The results of the three chemicals examined revealed that, as concerns the mortality, SDS and SSC2 are highly toxic even at low concentration. Only FINASOL OSR2, a modified molecule, seems to be nontoxic even at a high concentration; a low potential of the last substance was confirmed also for harm to gills. In conclusion, despite the indubitable usefulness of surfactants and oil dispersants, the potential toxicological effects of these chemicals on living beings must be taken into consideration, and the choice of less toxic molecules must be carefully considered.

\section{References}

1. Cserhàti T, Forgacs E, Oros G. Biological activity and environmental impact of anionic surfactants. Environ Int 2002;28:337-48.

2. Odokuma L0, Okpokwasili GC. Seasonal influences of the organic pollution monitoring of the New Calabar river, Nigeria. Environ Monit Assess 1997;45:43-56.

3. Baglinière C, Cenciarini J, Fernex F, et al. Problems of storage of various substances found in the interstitial waters on the surface sediments of the French continental shelf. Prog Water Technol 1980;12:79-88.

4. Romano JC, Garabetian F. Photographic records of sea-surface 
microlayers as a survey of pollution daily rhythm in coastal waters. Mar Environ Res 1996;41:265-79.

5. Tolosa I, Readman JW, Blaevoet A, et al. Contamination of Mediterranean (Côte d'Azur) coastal waters by organotins and Irgarol 1051 used in antifouling paints. Mar Pollut Bull 1996;32:335-41.

6. Staples E, Penfold J, Tucker I. Adsorption of mixed surfactants at the oil-water interface. J Phys Chem 2000;104:606-14.

7. Laemmli UK. Cleavage of structural proteins during the assembly of the head of bacteriophage T4. Nature 1970;227:680-5.

8. Lawrence MJ. Surfactant systems: microemulsions and vesicles as vehicles for drug delivery. Eur J Drug Metab Ph 1994;19:257-69.

9. Singer MM, Tjeerdema RS. Fate and effects of the surfactant sodium dodecyl sulphate. Rev Environ Contam T 1993;133:95-149.

10. Kalmanzon E, Zlotkin E, Cohen R, Barenholz Y. Liposomes as a model for the study of the mechanism of fish toxicity of sodium dodecyl sulphate in sea water. Biochim Biophys Acta 1992;1103:148-56.

11. Partearroyo MA, Ostolaza H, Goni FM, Barbera-Guillem E. Surfactant-induced cell toxicity and cell lysis. Biochem Pharmacol 1990;40:1323-8.

12. Mackie AM, Singh HT, Fletcher TC. Studies on the effect of seastar (Marthasterias glacialis) saponins and synthetic surfactants in the plaice Pleuronectes platessa. Mar Biol 1975;29:307-14.

13. Byrne P, Speare DJ, Ferguson HW. Effects of a cationic detergent on the gills and blood chemistry of rainbow trout Salmo gairdneri. Dis Aquat Organ 1989;6:185-96.

14. Abel PD, Skidmore JF. Toxic effects of an anionic detergent on the gills of rainbow trout. Water Res 1975;9:759-65.

15. Abel PD. Mortality patterns in trout (Salmo trutta and S. gairdneri) exposed to an anionic detergent in relation to concentration and mechanisms of toxic action. Freshwater Biol 1978;8:497-503.

16. ICRAM 2005. Programma di ricerca TAXA. Sperimentazione di test tossicologici su organismi marini ai fini dell'applicabilità del D.D. 23.12.2002. Relazione finale. Available from: http://www.arpa. emr.it/dettaglio_documento.asp?id=1207\&idlivello=703

17. Pane L, Giacco E, Mariottini GL. Utilizzo di Tigriopus fulvus (Copepoda: Harpacticoida) in ecotossicologia. Saggi con disperdenti e tensioattivi. Biol Mar Medit 2006;13:348-9.

18. Pane L, Giacco E, Mariottini GL. Effect of surfactants on the reproduction of Tigriopus fulvus Fischer. Exp Biol Rep 2007;1:77-88.

19. Pane L, Giacco E, Mariottini GL. Uso di Tigriopus fulvus (Copepoda: Harpacticoida) nella valutazione del rischio ecotossicologico in ambiente marino. Biol Mar Medit 2007;14:186-8.

20. Giacco E, Greco G, Corrà $\mathrm{C}$, et al. Toxic response of two
Mediterranean crustaceans species to oil dispersants. Mar Environ Res 2006;62(Suppl.1):54.

21. Choules GL, Russell WC, Gauthier D. Duck mortality from detergent-polluted water. J Wildlife Manage 1978;42:410-4.

22. Russell WC, Choules GL, Gauthier DA. Detergents and waterfowl. J Zoo Anim Med 1981;12:10-3.

23. Gelli F, Savorelli F, Pregnolato L, et al. Impiego del branzino (Dicentrarchus labrax, L.) quale organismo bersaglio in test ecotossicologici, di bioaccumulo e in saggi finalizzati a valutazioni di genotossicità. In: Proceedings of the 35th Conference of the Italian Society of Marine Biology, Genoa, Italy, 2004 July 19-20. Genoa: Italian Society of Marine Biology Publ.; 2004. p 201.

24. Masini MA, Prato P, Uva BM, et al. Effetto di tensioattivi e disperdenti in Sparus aurata L. Biol Mar Medit 2007;14:164-66.

25. Morales-Caselles C, Jimenez-Tenorio N, de Canales ML, et al. Ecotoxicity of sediments contaminated by the oil spill associated with the tanker "Prestige" using juveniles of the fish Sparus aurata. Arch Environ Con Tox 2006;51:652-60.

26. OECD. Guideline for testing of chemicals. Fish, prolonged toxicity test: 14-day study, 204, adopted 4/04/1984. Paris, France: OECD Publ.; 1984.

27. OECD. Guideline for testing of chemicals. Fish, acute toxicity test, 203, adopted 17/07/1992. Paris, France: OECD Publ.; 1992.

28. Hamilton MA, Russo RC, Thurston RV. Trimmed Spearman Karber method for estimating median lethal concentrations in toxicity bioassays. Environ Sci Technol 1978;11:718-20.

29. Cohen AL. Critical point drying principles and procedures. Scan Electron Micros 1979;2:302-24.

30. Coons AH, Leduc EH, Connolly JM. Studies on antibody production. A method for the histochemical demonstration of specific antibody and its application to a study of the hyperimmune rabbit. J Exp Med 1955;102:49-59.

31. Masini MA, Ricci F, Prato P, Uva BM. Branchial morphology and ionwater transport proteins in Antarctic teleosts with different modes of life. Polar Biol 2007;31:31-7.

32. Chaturvedi V, Kumar A. Toxicity of sodium dodecyl sulfate in fishes and animals. A review. Int J Appl Biol Pharm Technol 2010;1:630-3.

33. Mallatt J. Fish gill structural changes induced by toxicants and other irritants: a statistical review. Can J Fish Aquat Sci 1985;42:630-48.

34. Ribelles A, Carrasco C, Rosety M. Morphological and histochemical changes caused by sodium dodecyl sulphate in the gills of giltheads (Sparus aurata). Eur J Histochem 1995;39:141-8. 